\title{
Donald S. Moore. Suffering for Territory: Race, Place and Power in Zimbabwe (Durham \& London, Duke University Press, 2005).
}

Maxwell Zhira, University of Alberta

Donald Moore's Suffering for Territory is a work of ambitious scholarship making a significant contribution to current agrarian research in Africa and the developing world. The book explores ongoing debates and conflicts over the ownership and use of land in Zimbabwe, linking these tensions to broader themes such as the definition of national belonging, governance, racial exclusion and inclusion, poverty and socioeconomic status. Using the case study of Kaerezi, a rural area situated on Zimbabwe's eastern boarder, Moore combines history and ethnography to knit a nuanced and compelling interpretation of the ongoing post-independence land conflicts in Zimbabwe.

The introduction of the book carries theoretical concepts used throughout the text to interpret historical change and daily activities. Drawing from a wide range of theorists including Marx, Gramsci and Foucault, Moore locates his work within the frameworks of "governmentality, spatiality and entanglements of power and practice", (29). In the first part of the book, Moore examines the various modes of power exercised on residents of Kaerezi by headmen, chiefs, the rainmaker and agents of the central government, all who sought to exercise authority by controlling access to land. He probes the initiatives and reaction of villagers to local power relations by describing everyday social and economic practices hinged on land and agrarian production. The second part of the book is firmly grounded in key historical realities that affected Kaerezians ranging from their migration and occupation of territory

Past Imperfect 
bordering Zimbabwe and Mozambique, to their incorporation into the expanding colonial frontier at the start of the $20^{\text {th }}$ century.

Moore's presentation of "racialized dispossession" which saw Kaerezians loosing much of their land to incoming white settlers is fascinating to read because it places the current conflicts over land in Zimbabwe in their broader historical context, thus evoking legacies of colonial dispossession as a major theme in African agrarian debates. In practice, land dispossession and subsequent efforts by both the colonial and postcolonial states to "modernize" the rural economy heightened microconflicts over territory, renewing ways of asserting possession and belonging by the Tangwena people of Kaerezi. Moore vividly captures the dynamics of "suffering for territory" by drawing on oral testimonies which reveal how villagers contested "entangled sovereignties" exercised by state bureaucrats, the village chief, his headmen and the rainmaker. The book's analysis of this hierarchy of power is innovative because it accords eminence to the rainmaker, whose crucial link with the natural environment allows him to survive modern grids of power imposed by an overly intrusive state.

The third section of Suffering for Territory challenges the disjuncture often made between the colonial and postcolonial eras by showing the endurance of colonial notions of development, power and modernization into the independence period. The book manages to create a strong sense of determination for survival by rural villagers whose daily "micropractices" appear trivial but make a vital contribution to a local economy separate from, but crucially attached to the larger national and global economies. Framed around several intertwined layers of inquiry, Suffering for Territory maps a dynamic sense of time and space, which avoids the old functionalist approach to history. However, due it its theoretical rigor, exhaustive detail and 
innovative analysis, the book poses a challenge to scholars accustomed to plain narrative accounts of history and ethnography.

This is compensated for by Moore's ethnographic approach, which brings his inquiry to full life, while his consultation of archival sources builds a terrain of collaborative evidence making the book useful to an audience engaging with contemporary Zimbabwe and the developing world. 